Barbara i Adam Podgórscy, Mitologia ślaska, czyli przywiarki slónskie. Leksykon i antologia ślquskiej demonologii ludowej, Wydawnictwo Kos, Katowice 2011, ss. 557.

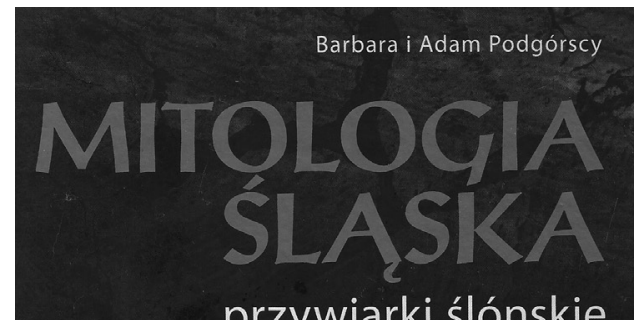

przywiarki ślónskie

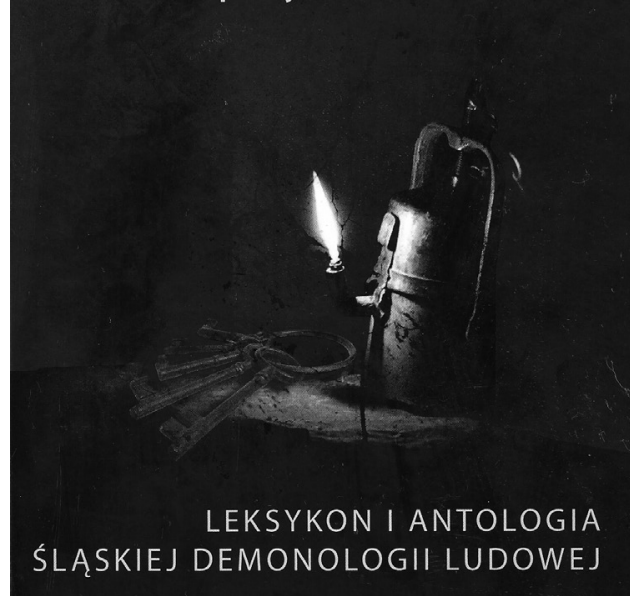

\section{Demoniczny miszmasz}

olska kultura ludowa, w węższym znaczeniu rozumiana jako materialno-duchowy dorobek rodzimych zbiorowości wiejskich, stanowiła kumulację wytworów społeczności tradycyjnej i nakładających się na nie w ciągu stuleci pierwiastków pochodzenia obcego (wplywy innych warstw społecznych i grup etnicznych, kultury oficjalnej oraz chrześcijańskiej). W wyniku absorbowania treści zewnętrznych $\mathrm{w}$ stosunku do rdzennej kultury, filtrowania ich przez chłopską umysłowość i włączania w obręb struktur światopoglądowych, zrodził się konstytuowany przez elementy o różnorodnej proweniencji konglomerat kulturowy, przybierający odmien- ny kształt $\mathrm{w}$ poszczególnych regionach kraju i danych momentach historycznych swojej ewolucji.

Niejednorodność źródeł kultury ludowej odzwierciedla charakterystyczny dla niej, synkretyczny typ wierzeniowości, kontaminujący relikty wyobrażeń pogańskich $\mathrm{z}$ elementami nauki Kościoła. Łączenie treści obu systemów wierzeniowych i specyficzna ich modyfikacja na potrzeby chłopskiej eksplikacji rzeczywistości zaowocowały wyklarowaniem się demonologii ludowej, o jakiej traktują liczne przekazy folklorystyczne, przede wszystkim opowieści podaniowe, których skarbnicą są XIX-wieczne zbiory polskich etnografów.

Współczesny badacz, podejmujący się opisu tradycyjnych wyobrażeń demonicznych, musi być świadom trudności, jakich nastręcza ta problematyka. Wiążą się one przede wszystkim z niemożnością weryfikacji dawnych przekazów wierzeniowych, w związku z którą nie sposób rozstrzygnąć, czy w opowiadane historie rzeczywiście wierzono, czy też reprodukowano je wylącznie na mocy konwencji; czy zachowane w źródłach etnograficznych relacje stanowią poważnie zmodyfikowany wariant popularnego w zbiorowości podania, ilustrującego konkretne wierzenie, czy stanowią jedynie wytwór wyobraźni informatora, kreującego quasi-podaniową fabułę dla usatysfakcjonowania nagabującego go etnografa, wreszcie - niejednokrotnie nie sposób orzec z pewnością o przekształceniu się memoratu w fabulat, a co za tym idzie - o fakcie włączenia go do wspólnotowego rezerwuaru tekstów.

Problematyka demonologiczna, kluczowa dla uchwycenia istoty chłopskiej wierzeniowości, zajmuje poczesne miejsce $\mathrm{w}$ polskich badaniach ludoznawczych. Prace poświęcili jej wybitni polscy etnografowie, folkloryści i historycy. W literaturze przedmiotu znaleźć można opracowania dotyczące wierzeń pogańskich, które położyły podwaliny pod kształtujące się na przestrzeni stuleci ludowe wyobrażenia demoniczne ${ }^{1}$, prace poświęcone procesom chrystia-

1 Zob. m.in. A. Gieysztor, Mitologia Słowian, wstęp K. Modzelewski, posłowie L. P. Słupecki, oprac. A. Pieniądz, Warszawa 2006; A. Brückner, Mitologia słowiańska i polska, wstęp i oprac. S. Urbańczyk,

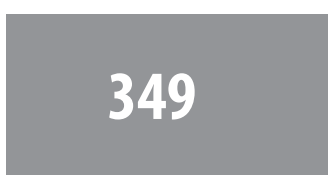


nizacyjnym prowadzonym w celu wyrugowania przedchrześcijańskich wierzeń i praktyk kulto$w_{y c h}^{2}$ oraz traktujące o chłopskiej religijności jako konglomeracie przekonań pogańsko-chrześcijańskich ${ }^{3}$, omówienia kwestii kulturowej obecności oraz funkcji demonów ludowych ${ }^{4}$, propozycje typologii zaludniających chłopską wyobraźnię istot nadzmysłowych ${ }^{5}$ czy wreszcie folklorystyczne analizy tekstów ludowych, zwłaszcza podania wierzeniowego ${ }^{6}$.

$\mathrm{W}$ poczet publikacji poświęconych demonologii ludowej wpisuje się wydana niedawno praca Barbary i Adama Podgórskich Mitologia śląska, czyli przywiarki slónskie, będąca trzecią $\mathrm{w}$ dorobku autorów pozycją, podejmującą problematykę demonologiczną, ujmującą przy tym prezentowane treści w formie haseł leksykonowych.

W 2000 roku ukazała się opracowana przez pasjonatów ludowych wierzeń Encyklopedia demonó $w^{7}$, stanowiąca bodajże pierwszy na gruncie piśmiennictwa polskiego tak obszerny wykaz istot demonicznych, przedstawiony $\mathrm{w}$ postaci hasel, ich definicji oraz ilustrujących je cytatów. Z uznaniem podkreślić należy pionierski charakter formalny wydawnictwa oraz włożony w jego przygotowanie wysiłek autorów, związany ze żmudną pracą poszukiwawczą. Nie sposób jed-
Warszawa 1980; S. Urbańczyk, Religia pogańskich Stowian, Kraków 1947.

2 Zob. S. Bylina, Chrystianizacja wsi polskiej u schyłku średniowiecza, Warszawa 2002; idem, Religijność późnego średniowiecza, Warszawa 2009.

${ }^{3}$ Zob. m.in. S. Czarnowski, Kultura religijna wiejskiego ludu polskiego, [w:] idem, Dzieła, t. 1: Studia z historii kultury, oprac. N. Assorodobraj, S. Ossowski, Warszawa 1956, s. 88-107; R. Tomicki, Religijność ludowa, [w:] Etnografia Polski. Przemiany kultury ludowej, t. 2, red. M. Biernacka, M. Frankowska, W. Paprocka, Wrocław 1981, s. 29-69; K. Kwaśniewicz, Tradycyjna religijność ludowa, „Rocznik Muzeum Etnograficznego w Krakowie" 1983, t. 8, s. 25-39.

${ }^{4}$ Zob. m.in. K. Moszyński, Kultura ludowa Słowian, t. 2, Warszawa 2010; B. Baranowski, Wśród upiorów i wilkołaków, Łódź 1981.

${ }_{5}^{5}$ Zob. L. Pełka, Polska demonologia ludowa, Warszawa 1987.

${ }^{6}$ Zob. D. Simonides, Śląski horror. O diabłach, skarbnikach, utopcach i innych strachach, Katowice 1984.

7 B. i A. Podgórscy, Encyklopedia demonów. Diabły, diabełki, jędze, skrzaty, boginki... i wiele innych, Wrocław 2000. nak przejść obojętnie nad mankamentami opracowania.

Zgodnie $\mathrm{z}$ wyłożonym we wstępie zamysłem, publikacja stanowić miała przewodnik encyklopedyczny po polskiej demonologii ludowej, rozbudowany o „zagraniczne odpowiedniki” (s. 7) rodzimych demonów, skonstruowany na podstawie „dzieł źródłowych” Oskara Kolberga, Ryszarda Berwińskiego, Łukasza Gołębiowskiego i Kazimierza Wójcickiego (s. 8) oraz „poważne opracowania” Bohdana Baranowskiego, Leonarda Pełki, Kazimierza Moszyńskiego i Doroty Simonides (s. 8). Właściwa część publikacji zdradza jednak, że wstępne deklaracje rozminęly się z efektami pracy autorów.

Konsekwencją przyjętej przez Podgórskich metody tworzenia encyklopedii, polegającej na zestawianiu rozproszonych $w$ innych opracowaniach przekazów o demonach w oparciu wyłącznie o bliżej niedookreślone kryterium demoniczności, jest bałagan poznawczy wyrastający z pomieszania różnych porządków: wierzeniowych (demony pogańskie i chrześcijańskie), chronologicznych (demony dawne i współczesne), artystycznych (źródła ludowe i literackie). $\mathrm{W}$ ten sposób w jednym tomie zestawiono mamunę, południcę i topielca obok Asmodeusza, Beliala i Belzebuba, Ancykrysta obok Trzygłowa i Swarożyca, trupiszona (definiowanego jako „demon ze współczesnych polskich opowieści wierzeniowych, utożsamiany z duszą człowieka zmarłego, powstającego $\mathrm{z}$ grobu $\mathrm{w}$ rozmaitych wcieleniach" - s. 400) obok strzygi, czy w końcu Twardowskiego i Świteziankę obok płanetnika i dziwożony. Ów nieład spotęgowany został poprzez włączenie do opracowania haseł z zakresu magii i lecznictwa, które z demonologią ludową łączą się jedynie na zasadzie luźnych skojarzeń (np. czary, klątwa, macica, uroki, znachor).

Zastrzeżenia budzi ponadto sposób konstruowania haseł, odznaczający się wysokim stopniem niekonsekwencji. Obok wyjaśnianego pojęcia pojawia się bardziej lub mniej wyczerpująca definicja, za którą stoi, choć nie jest to regułą, ilustrujący ją cytat, pochodzący bądź to z materiałów źródłowych (przytaczanych za pośrednictwem prac innych autorów), bądź z opracowania naukowego, bądź też z utworu literackiego, w którym występuje omawiana postać (np. Dusiołek Bolesława Leśmiana, Konopielka Edwarda 
Redlińskiego, Latawica Marii Konopnickiej, Piosenka o Ubożęciu Kazimiery Iłłakowiczówny).

W pięć lat po wydaniu Encyklopedii demonów ukazała się kolejna praca Podgórskich, poświęcona problematyce demonologicznej - Wielka księga demonów polskich ${ }^{8}$, do złudzenia przypominając swoją poprzedniczkę. Leksykon z 2005 roku stanowi w zasadzie rozbudowaną wersję encyklopedii, zawierającą uzupełnienia wcześniejszych haseł (najczęściej o kolejne cytaty), nowe pozycje oraz liczne materiały ilustracyjne.

W związku z tym, że praca powstała w oparciu o stosowane wcześniej metody, powiela ona wady Encyklopedii demonów, nie jest przy tym wolna od innych niedoskonałości. Zastanawia już chociażby sam podtytuł nowego opracowania. W związku z niejednoznacznym jego sformułowaniem (Leksykon i antologia demo no log i i ludowej - podkr. O.W.), należy wnosić, że zamiarem autorów było zestawienie tekstów, dotyczących prezentowanych w publikacji demonów. I w tym wypadku uderza jednak niekonsekwencja w zakresie doboru źródeł, obok bowiem przywoływanych za pośrednictwem innych autorów przekazów ludowych, pojawiają się wyimki z prac naukowych, tekstów literackich, a nawet Biblii.

Kontynuacją prac Podgórskich nad demonologią ludową jest wydana w ubiegłym roku Mitologia ślaska, koncentrująca się tym razem na wierzeniowości regionalnej. Adresowana do „przeciętnego czytelnika” (s. 27) praca, jak podkreślają we wstępie jej autorzy, wyrosła z potrzeby rewizji niektórych $\mathrm{z}$ dotychczasowych ustaleń śląskich folklorystów (s. 21-22) oraz dla „oddania czci” folklorystom niemieckim za ich wkład w opracowywanie przekazów wierzeniowych o polskiej proweniencji (s. 22). W przekonaniu o randze prac zachodnich sąsiadów, autorzy sięgnęli po publikacje niemieckojęzyczne, co poczytać należy za walor leksykonu. Na uznanie zasługuje ponadto posiłkowanie się śląskimi przekazami gwarowymi, które wprowadzają czytelnika w szczególną atmosferę regionu.

Wobec publikacji sformułować można jednak liczne zarzuty. I tak, obszerność tomu,

${ }^{8}$ B. i A. Podgórscy, Wielka księga demonów polskich. Leksykon i antologia demonologii ludowej, Katowice 2005. zbliżonego rozmiarowo do pracy na temat demonologii ogólnopolskiej, sugerować może szczególne bogactwo obecnych w kulturze Śląska istot nadziemskich. Okazuje się jednak, że - oprócz demonów decydujących o regionalnej specyfice demonologii przedstawianego obszaru (np. skarbnik, erdgajst, Szarlej) - do opracowania włączono opisy stworów o ponadregionalnym zasięgu występowania i o różnej proweniencji (np. południca, potępieniec, Lucyfer), prezentowane - niejednokrotnie w identycznej formie - w pracach poprzednich (np. aniol upa$\left.\mathrm{dly}^{9}\right)$. W konsekwencji tak szerokiego doboru definiowanych treści uniemożliwia się czytelnikowi dotarcie do szczególnego kolorytu śląskiej wierzeniowości, którego odmalowanie założyli autorzy. W zalewie leksykonowych rozmaitości nie sposób odseparować treści powszechnych, nakładających się w poprzek podziałów etnograficznych, od zjawisk typowo śląskich, decydujących o kulturowej wyjątkowości regionu.

Znalazły się tu ponadto hasła niezwiązane z problematyką demonologiczną: wcześniejsze, występujące również w Encyklopedii demonów i Wielkiej księdze demonów polskich (np. odczynianie uroków) i nowe (np. apotropeiony roślinne, postrzał). Ich włączenie w obręb opracowania jeszcze bardziej oddala uwagę czytelnika od tytułowych kwestii, rodzi ponadto pytanie o sens kompilowania w leksykonie poświęconym demonom wybiórczych i szczątkowych informacji z zakresu ludowych praktyk magicznych i leczniczych.

Praca „rozrasta się” dodatkowo w wyniku dołączania do haseł odsyłających, stanowiących przeważnie gwarowy wariant nazewniczy (np. bioła pani, Iwon, utoplarek), kolejnych tekstów ilustrujących danego demona (dla tekstowego potwierdzenia obecności danego sposobu określania przedstawianej istoty), multiplikujących opowieści zamieszczone przy haśle głównym. Zabieg ten, dyktowany dążeniem do rozbudowania antologii, wprowadza do opracowania niepotrzebny chaos i sztucznie zwielokrotnia demoniczne byty.

9 Zob. B. i A. Podgórscy, Anioł upadły, [hasło w:] Encyklopedia demonów, s. 18-19; Wielka księga demonów polskich, s. 29-30; Mitologia śląska, s. 32-33. 
Odrębny problem stanowi nieweryfikowalność omawianych kwestii, powodowana, z jednej strony, wadliwym oznaczaniem źródeł cytatów (zastosowany system skrótów pomija numerację stronic), z drugiej zaś - brakiem informacji o jakościowej i ilościowej reprezentacji poszczególnych demonów. Brak ten zaciera różnice w zakresie kulturowej doniosłości przedstawianych stworów i prowadzić może do błędnego wniosku o zbliżonej częstotliwości występowania najbardziej rozpoznawalnych i charakterystycznych tak dla śląskiej, jak i ogólnopolskiej demonologii istot $\mathrm{z}$ tymi, które $\mathrm{w}$ przekazach pojawiają się incydentalnie.

Lektura pracy Podgórskich zdradza niekłamaną fascynację autorów - pasjonatów Śląska i popularyzatorów jego kultury - zagadnieniami branymi na warsztat. Jednakże pokazuje ona jednocześnie merytoryczne niedostatki publikacji, wspólne zresztą dla wszystkich omówionych wyżej wydawnictw. Ich najpoważniejszym mankamentem jest mechaniczne włączanie w obręb opracowania wszelkiego typu tekstów traktujących o demonach, związane $\mathrm{z}$ niekonkretnym pojmowaniem kultury ludowej $i$ jej formalnego skomplikowania. W publikacjach tych uderza prezentowanie złożonej problematyki demonologicznej w stylu iście popkulturowym: uproszczonym, łączącym w sobie elementy różnych porządków i obiegów, skierowanym do masowego czy - jak chcą autorzy - „przeciętnego” odbiorcy. Zastrzeżenia budzi również brak ostrych kryteriów doboru prezentowanych zagadnień z zakresu ludowej demonologii, jak i kultury tradycyjnej w ogóle, a także powielanie publikowanych uprzednio treści. Wszystko to obniża oryginalność i wartość poznawczą demonologicznych leksykonów Podgórskich.

Olga Wachcińska - absolwentka filologii polskiej i kulturoznawstwa, doktorantka w Zakładzie Folklorystyki i Literatury Popularnej Uniwersytetu Mikołaja Kopernika w Toruniu. Współredaktorka studenckiego czasopisma naukowego "Tekstura. Rocznik Filologiczno-Kulturoznawczy". W latach 2009-2011 przewodnicząca Koła Naukowego Folklorystów. Zajmuje się folklorem tradycyjnym i współczesnym, kulturą ludową i popularną oraz związkami literatury i folkloru.
Dominika Urbańska-Galanciak, Homo players. Strategie odbioru gier komputerowych, Wydawnictwa Akademickie i Profesjonalne, Warszawa 2008, ss. 262.

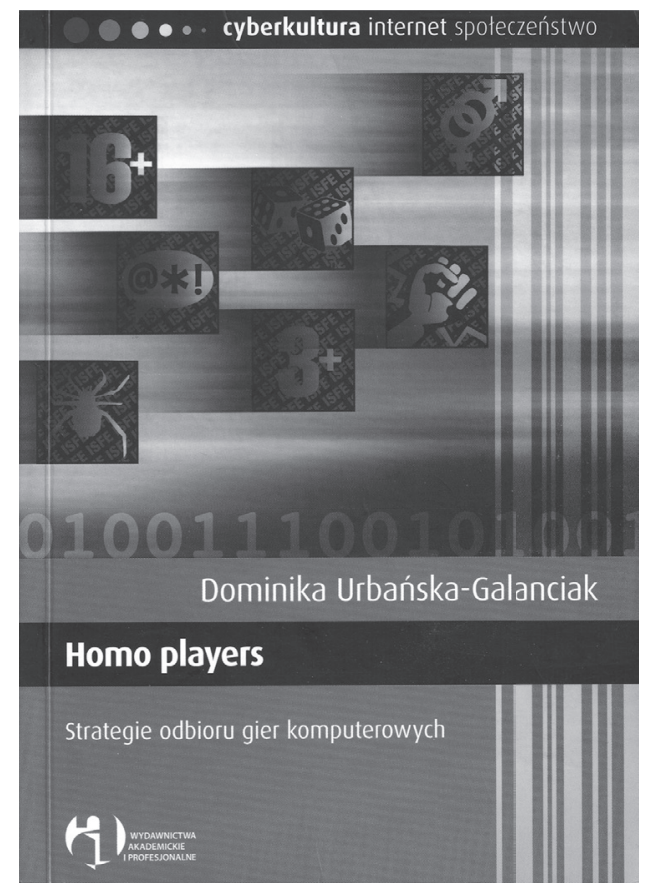

\section{Czwarty wymiar rzeczywistości}

olski rynek wydawniczy nie obfituje w tytuly poświęcone tematyce gier komputerowych. Jedną z nielicznych pozycji dotyczących tego typu rozrywki jest praca Dominiki Urbańskiej-Galanciak - doktor nauk humanistycznych w zakresie kulturoznawstwa i członkini Polskiego Towarzystwa Badania Gier. Przedmiotem jej rozprawy Homo players. Strategie odbioru gier komputerowych jest problematyka recepcji oraz sposobów użytkowania gier komputerowych przez środowisko graczy, któremu również poświęcona została duża część tej publikacji.

Krótka historia refleksji nad tematyką gier komputerowych na gruncie polskiej nauki wynika przede wszystkim z niedawnego wzrostu za- 